\title{
Dynamic modeling of major depressive disorder: Calculating the rate of occurrence and recurrence
}

\author{
Seyed Esmaeil Hosseini' ${ }^{\text {** }}$ (D), Mohammad Pooyan², Alireza Valizadeh ${ }^{3}$, Alireza Moradi ${ }^{4}$ \\ 1. PhD in Cognitive Modeling, Institute for Cognitive Science Studies, Tehran, Iran \\ 2. Associate Professor in Biomedical Engineering, Faculty of Engineering, Shahed University, Tehran, Iran \\ 3. Associate Professor in Physics, Department of Physics, Institute for Advanced Studies in Basic Sciences (IASBS), Zanjan, Iran \\ 4. Professor in Clinical Psychology, Department of Psychology, Kharazmi University, Tehran, Iran
}

Recieved: 16 Jul. 2018

Revised: 14 Jan. 2019

Accepted: 14 Feb. 2019

\section{Keywords}

Major depression disorder

Dynamic system model

Rate of occurrence

Recurrence of depression disorder

Corresponding author

Seyed Esmaeil Hosseini, PhD in

Modeling in Cognitive Sciences,

Institute for Cognitive Science

Studies, Tehran, Iran

Email: Sehosseini93@gmail.com

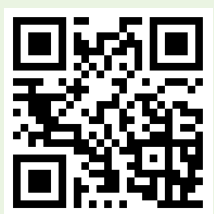

\section{Abstract}

Introduction: The major depressive disorder is a long-lasting disorder that results in major functional and social disorders. According to the World Health Organization, the major depressive disorder will become the second leading cause of disease worldwide in 2020. The purpose of the present study was to present a second-orderer nonlinear dynamic model underlying depression disorder using computational modeling that can justify the conditions of occurrence and recurrence of depression.

Methods: In this model, two mathematical equations were presented which consisted of several effective quantities in the generation of major depressive disorder such as the volume of the hippocampus, serotonin levels, amygdala volume, psychological external factors and unpredictable processes and the history of previous periods of the patient were considered. The data were analyzed on the 1002 depressed people periods, over a 64-year normal life span.

Results: The results of the presented model show that in the dynamic model, the duration curve of depression in patients under the antidepressant drugs and the third wave cognitive behavioral therapy was widespread, with an average of 1019 days.

Conclusion: The study developed a mathematical framework, which will eventually lead to the development of more detailed models for a major depressive disorder and a better perception of the major depressive disorder and its effects on cognitive processes.

Citation: Hosseini SE, Pooyan M, Valizadeh A, Moradi A. Dynamic modeling of major depressive disorder: Calculating the rate of occurrence and recurrence. Advances in Cognitive Sciences. 2020;21(4):33-45. 
())

\section{مدلسازى ديناميكى اختلال افسردكى اساسى و محاسبه سرعت وقوع: باز تشت دورههاى اختلال افسردىى}

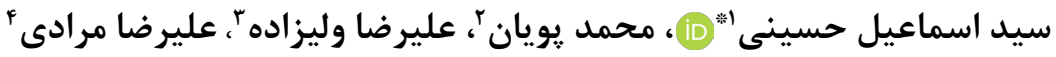

1. ا. دكترى مدل سازى شناختى، مؤسسه علوم شناختى، تهران، ايران

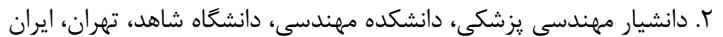

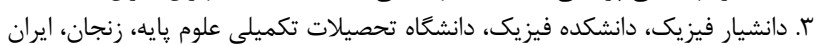

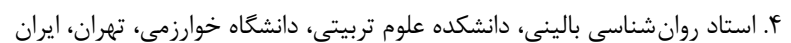

مقلهمه: اختلال افسردگى اساسى، يك اختلال طولانى و پِايا است و منجر به ايجاد اختلالات عملكردى و اجتماعى اساسى مى شود. طبق كفته سازمان بهداشت جهانى، اختلال افسردكى اساسى در سال •r.r به دومين عامل اصلى بيمارى در سراسر جهان تبديل خواهد شد. هدف از انجام اين يروهش، ارائه يك مدل ديناميكى غيرخطى مرتبه دوم براى اختلال افسردىى اساسى با استفاده از مدل سازى محاسباتى بود كه بتواند شرايط وقوع و بازگشت دورههاى افسردگى را توجيه كند. روش كار: در اين مدل دو معادله رياضى ارائه شده بود كه، از جند كميت مؤثر در ايجاد اختلال افسردگى اساسى مانند حجم هييوكامٍ، سطح سروتونين، حجم آميكدال، عوامل خارجى روانشناختى و فرايندهاى غير قابل بيشبينى، تشكيل يافته بود و سابقه دورههاى قبلى بيمار در نظر كرفته شده است. در مدلسازى صورت كرفته، دادهاى مدل، بر

$$
\text { روى دورههاى ץ..1 فرد افسرده، در بازه زمانى يك عمر طبيعى 4F ساله، بررسى شد. }
$$

يافته ها: در مدل ديناميكى، منحنى توزيع مدت دوره افسردگى در بيماران تحت درمان دارويى و شناختى رفتارى موج سوم، بسيار گسترده بوده و ميانگين آن 19 آ روز است. نتيجه گَيرى: در اين يُوهش يك حارجوب رياضى توسعه يافت، كه در نهايت به توسعه مدل هاى مفصل تر براى اختلال افسردكى اساسى و درك بهتر اين اختلال و اثرات آن بر فرايندهاى شناختى، منجر خواهد شد.
دريافت:

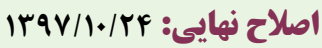

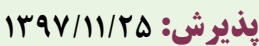
وازمهاى كليدى اختلال افسردكى اساسى مدل سيستمهاى ديناميكى سرعت وقوع سرعت برگشت اختلال افسردىى

نويسنده مسئول سيد اسماعيل حسينى، دكترى مدلسازى شناختى، مؤسسه علوم شناختى، تهران، ايران

ايميل:Sehosseini93@gmail.com

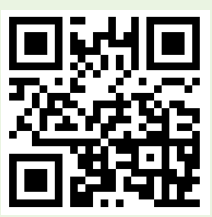

dol doi.org/10.30699/icss.21.4.33

مقلدمه

كفته سازمان بهداشت جهانى، MDD در سال • •r ب به دومين عامل اصلى بيمارى در سراسر جهان تبديل خواهد شد (ّ). اين اختلال اولين دليل بازنشستخى زودرس و غيبت از كار به دليل بيمارى، در بسيارى از كشورهاى ارويايى است (4). افراد مبتلا به MDD، اغلب علاقه خود را به فعاليتهايى كه زمانى از آن لذت مىبردند، از دست مىدهند و
اختلال افسردگى اساسى (Major Depressive Disorder (MDD)، يك اختلال طولانى و يايا است و منجر به ايجاد اختلالات عملكردى و اجتماعى اساسى مىشود ( (1). افسردگى جالشى بزرگ براى سلامت

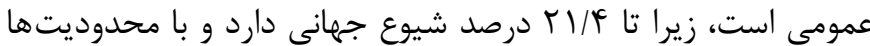
و هزينهاى بالا براى فرد، خانواده و جامعه مرتبط است (r). طبق 
(4). اما، تعريفى كه محققان مختلف از حالات اختلال افسردگى ارائه مىدهند، هماهنگ نيستند. لذا تفسير نتايج دشوار مىشود و نمىتوان بين تحقيقهاى مختلف مقايسه انجام داد (I) IV). براى بيشتر افراد داراى اختلال افسردگى اساسى، عود يس از بهبودى، يك يديده رايج

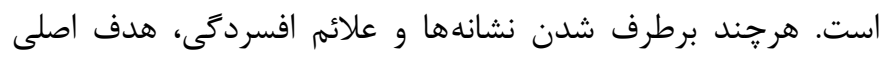

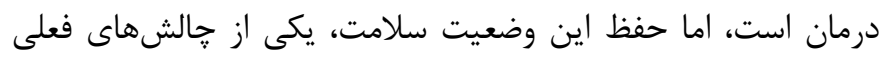

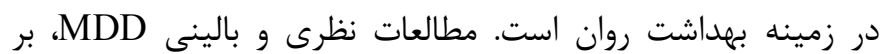
درصد بالاى عود پِ از بهبودى تأكيد كردهاند (1)، 19). هرجه تعداد دورههاى قبلى بيشتر باشد، به همان اندازه، عود سريعتر رخان

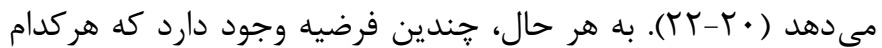
توضيح جداكانهاى، از اختلال شناختى در MDD ارائه مى دهد (بr). فرضيه هاى اختلال شناختى خاصى، ادعا مى كنند كه MDD با اختلال مشخص در حوزههاى شناختى خاص، به ويزه در حافظه و عملكرد

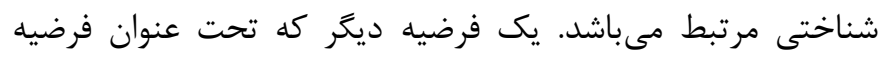

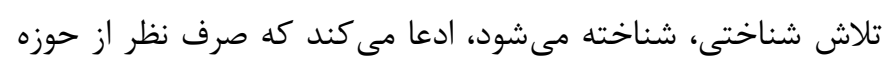

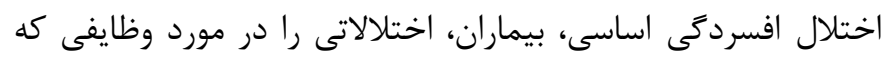
نياز به توجه و ظرفيت شناختى دارند، نشان مى دهند. در حالى كه إسى إنى عملكردهاى آنها در مورد وظايف غيرارادى، طبيعى مىباشد (YF). بر اساس يزوهش هاى انجام شده در طى دهه گَذشته، مشخص شده است كه نقايص شناختى در MDD منجر به كاهش كيفيت زندكى مىشود

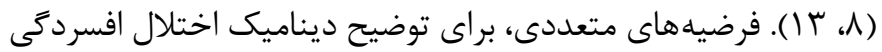
اساسى وجود دارد، به هرحال، همه فرضيه ها، محدوديتهايى دارند،

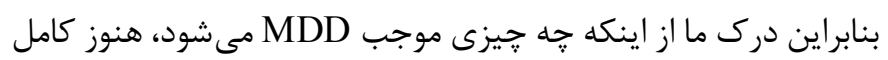
نيست. بهتر است كه فرضيه هاى موجود ادغام شوند.

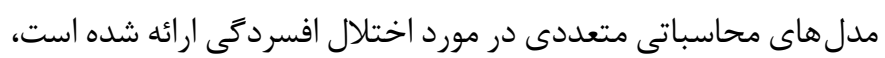
يكى از روش هاى بررسى افسردحى، بر رسى اختلال به عنوان يك سيسته ديناميك است. يك سيستم ديناميكى سيستمى است كه مى تواند براى توصيف رفتارهاى غيرخطى در طول زمان از بازخورد كميتها استفاده كند (T)). ارائه مدلسازى ديناميكى بيمارىهاى روانى بيشتر از دو دهه قدمت دارد. در يك يزوهشى، ديناميك افسردىى با مجموعهاى از قوانين توليد ( اكر_آنغاه)، در يك مدل مجازى، هفت متغير مربوط به درديه

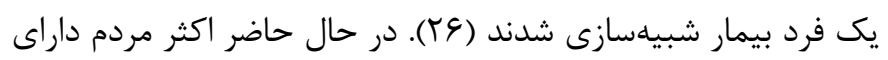
تلفن هوشمند هستند، اين تلفنهاى هوشمند حاوى اطلاعات غنى از

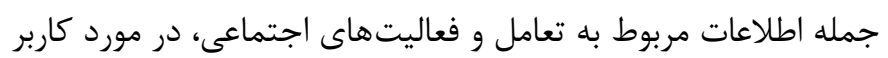
هستند، اين اطلاعات مى تواند براى ييش بينى خلق و خو، اعمال شود. در يزوهشى، برنامهاى ساخته شده است كه بر اساس دادهاى كَشى هاى

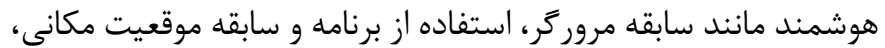

در انجام فعاليتهاى روزمره، دجار مشكل مىشوند. كاهى اوقات، آنها ممكن است احساس كنند كه زندگى ارزش ندارد (ه، ؟). اطلاعات

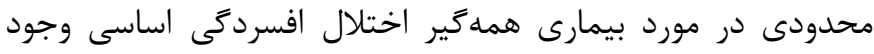

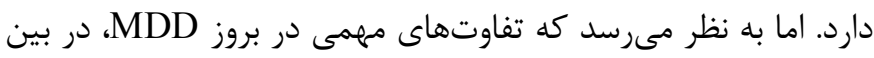

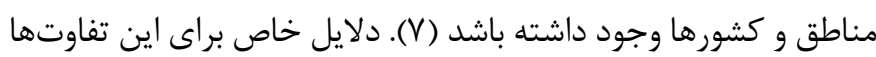

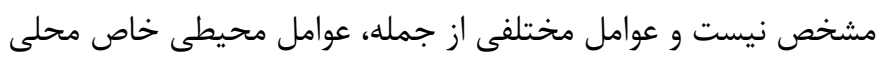

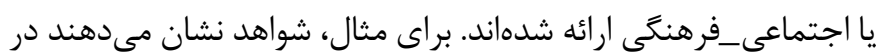
برخى مناطق ارويا مانند جنوب آن، هون يك محيط اجتماعى و سنتى دارند، خودكشى و افسردگى در آنجا كمتر رايج است (^). اين اختلال يكى از شايعترين بيمارىهاى روانى در ايالات متحده آمريكاست. در

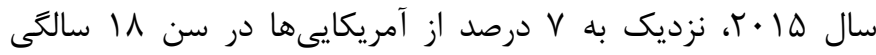
يك دوره از اختلال افسردگى اساسى داشتند (9). آمار كل اختلالات

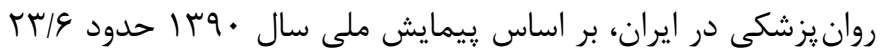

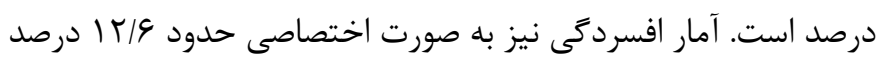

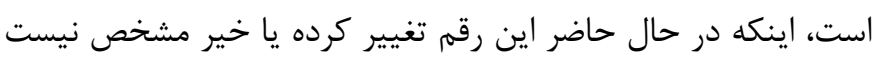

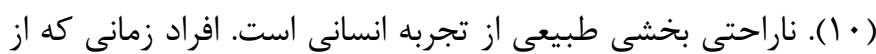

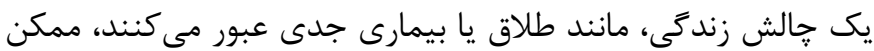

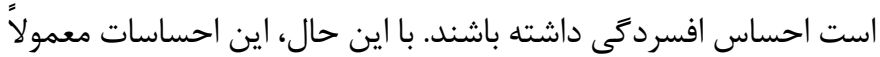
كوتاه هستند. زمانى كه فردى احساس شديد غم را براى مدت زمان طولانى تجربه مىكند، ممكن است دجار MDD شده باشد (11). افسردىى در بين مبتلايان بيمارىهاى مزمن مانند ديابت، بيمارىهاى

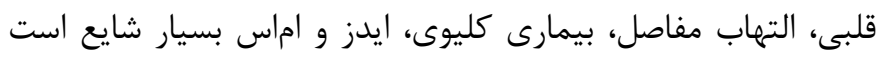

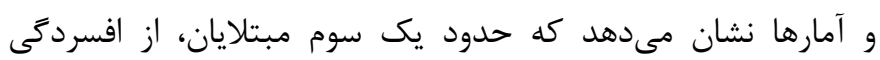

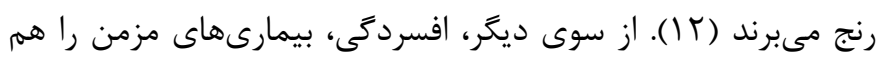

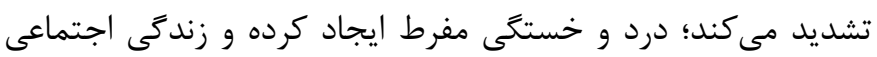
شخص را مختل و افراد را از روابط اجتماعى دور مى كند. تخمين زده دهد مىشود كه تا • و درصد از خودكشىها در سال، در سراسر جهان در

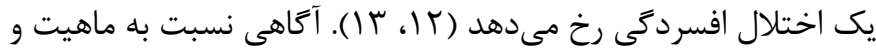
علل افسردىى در طول سالها، بِيشرفت زيادى داشته است؛ هرجند اين

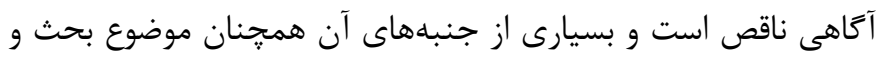

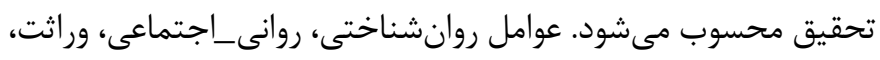

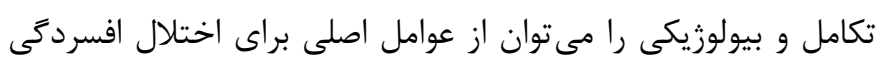

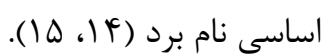

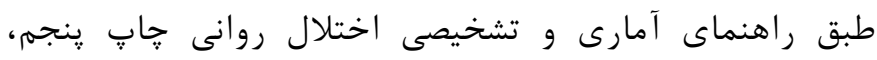
(Diagnostic and Statistical Manual of Mental Disorder (DSM-5)) مشخصه بارز دوره افسردىى دورهاى است كه دست كم أl روز طول

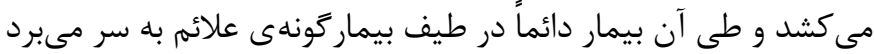


رواندرمانى امكان يذير است. تمركز اصلى اين مقاله بر مدل كيفى يشت

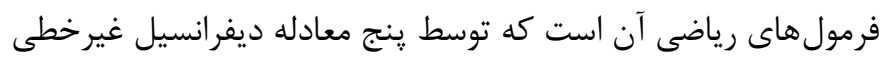

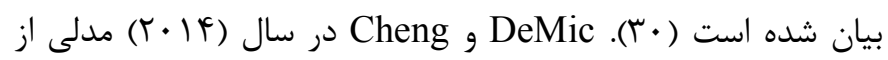

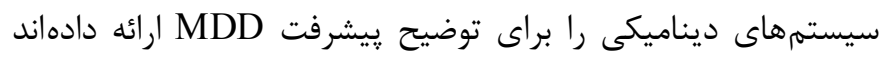

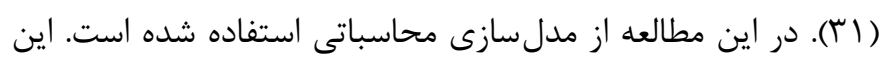

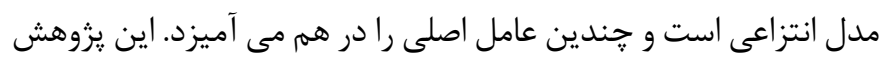

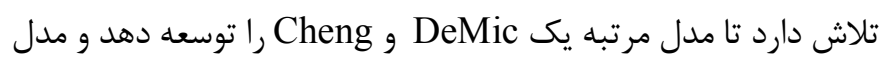

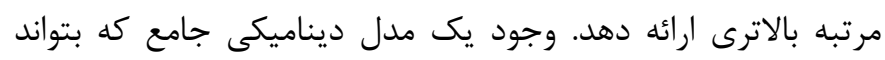

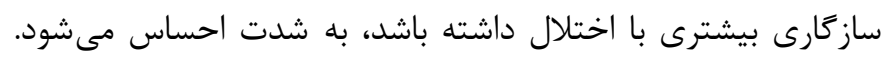

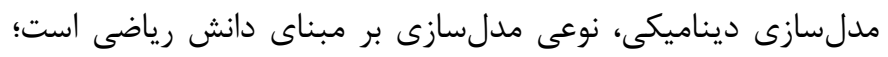

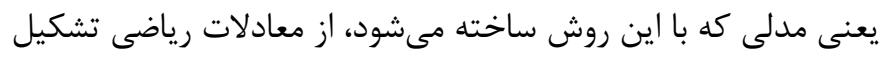

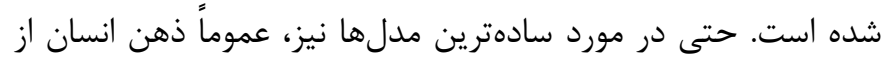

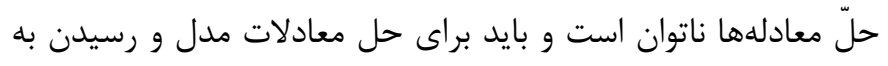

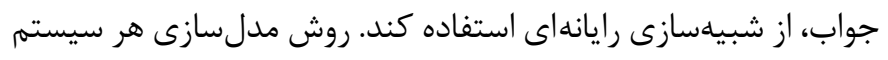

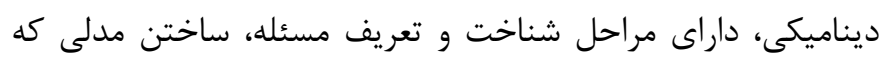

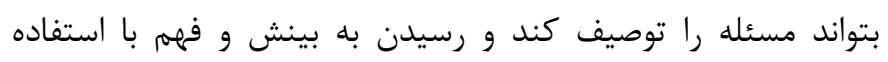

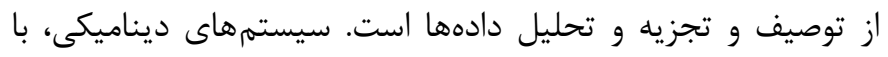
بسيارى از نظريههاى موجود در مورد MDD، ساز گار مىباشد. اكرجه

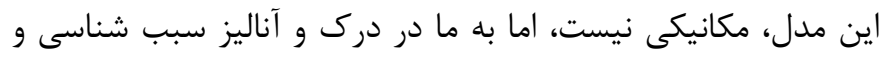

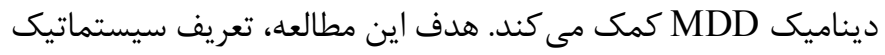

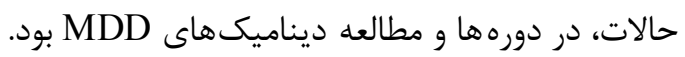

\section{روش كار}

در يزوهشى كه DeMic و Cheng از دانشخاه Bochum در سال F أ • انجام داده است مدل ديناميكى مطرح كرده است كه، براى مدل سازى داند ديناميك افسردگى ابتدا به روشى براى توصيف حالت فرد، كه آيا فرد

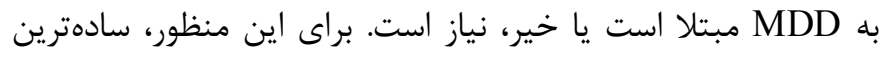
روش ممكن انتخاب شده است، كه قرار است حالت فرد را با متغير واحد

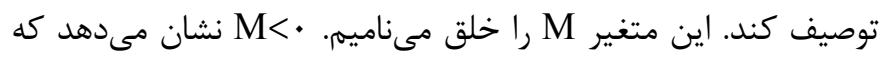
فرد به علائمى مبتلا است كه تداعى كننده

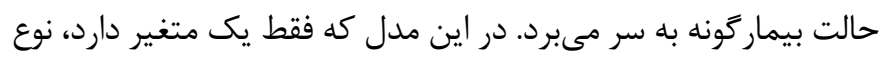

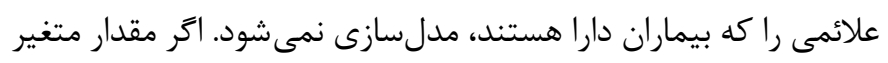
حالت منفى باشد، به اين معنا است كه فرد علائم كافي بيمارى را دار دارا

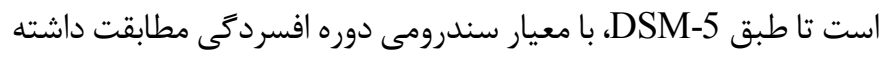

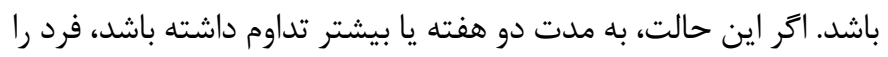

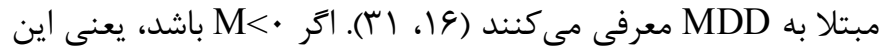

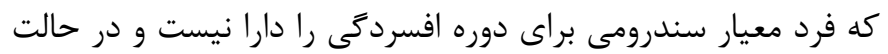

خلق و خوى را يِشبينى مى كند. با استفاده از نرمافزار نصب شده بر

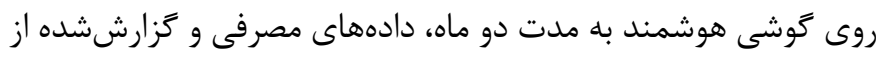

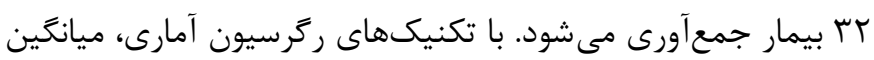

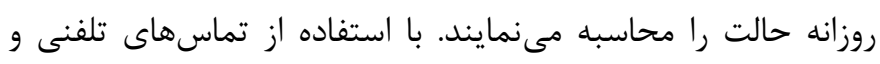

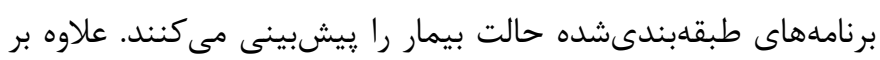

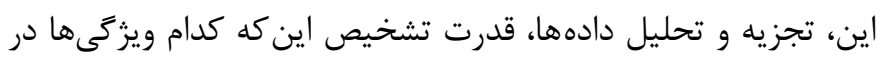

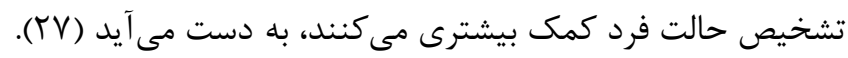
در يزوهشى، طول دورههاى افسردگى مورد مطالعه قرار گرفته است.

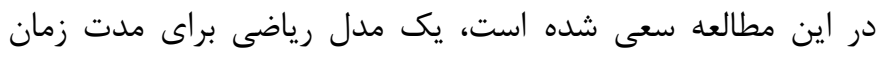

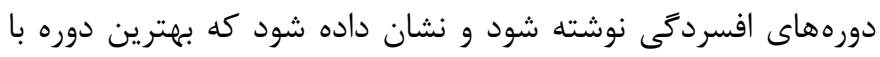

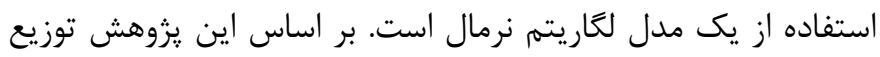

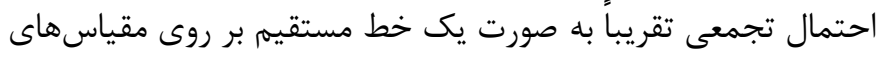

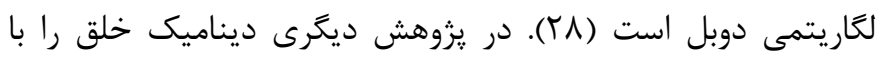

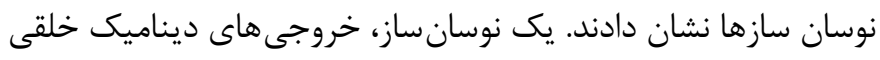

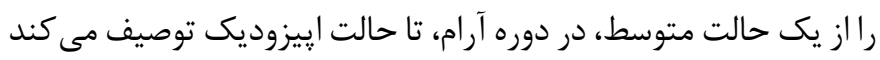

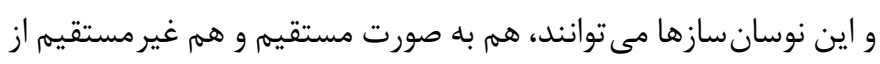
طريق نويز، جفت شوند. افزايش سطح جفتشدكى در حضور نويز باعث افزايش تمايل فزاينده سيستم براى نوسان شده و همجنين بر ميزان

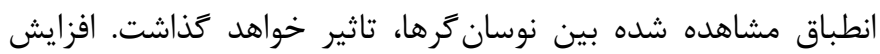

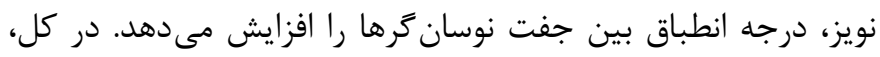
ديناميك خلقى توسط دو نوسانساز مستقل توصيف مى شود. علاوه بر اين، سطوح متوسط افسردحى و تصادفى بودن (تغييريذيرى) نيز در كنترل ديناميك خلقى و نوسانات خلقى مههم و ضرورى هستند. از از

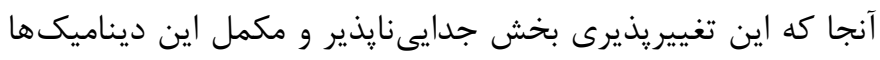

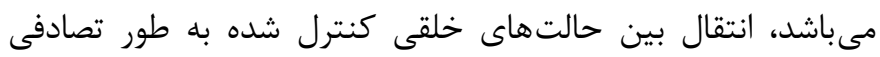

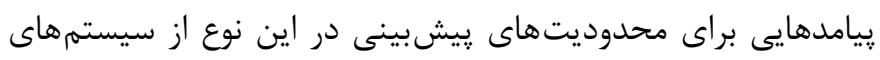

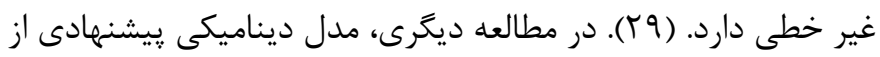
ينج متغير حالت تشكيل شده است (شدت مساله، موفقيت و ييشرفت

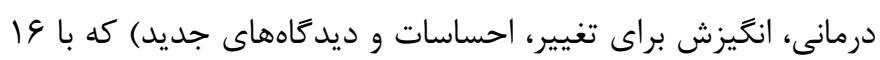

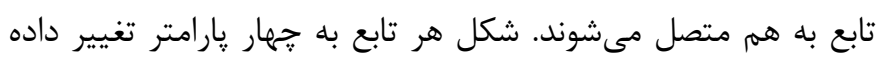

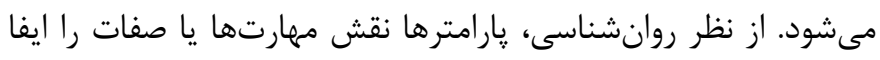

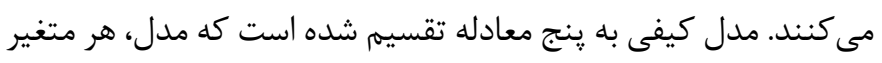
را به عنوان تابعى از متغيرهاى ديخر توليد مى كند.

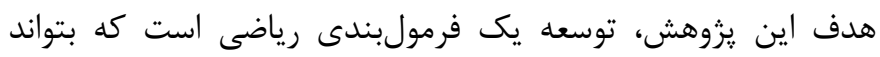

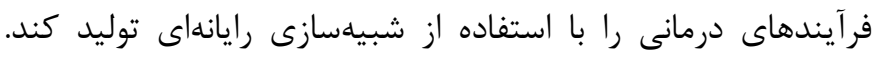

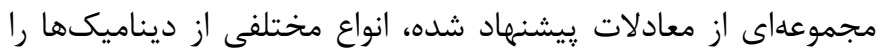
ايجاد مى كند و نشان مىدهد كه شبيهسازى مبتنى بر مدل فرآيند 
كه داراى دو حالت پايدار باشد، يك حالت كه با حالت افسردگى متناظر است و حالت ديكر كه با حالت غير افسردگى تناظر دارد. لذا، ديناميك MDD با يك معادله درجه يك جند جملهاى مدل سازى شده است: $\frac{d M}{d t}=-a(M-b)(M-c)(M-d)+I+\varepsilon$

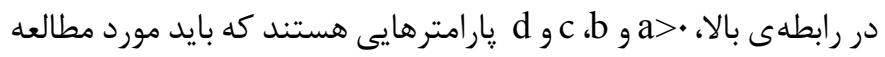

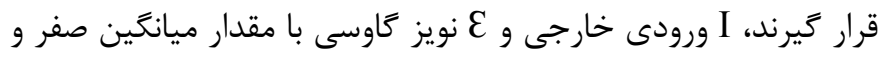
انحراف معيار يك براى تعيين مقياس است (آ). سيستم ديناميكى در معادلهى (r) داراى دو نقطه ثابت يايدار است، كه با نقطه ثابت

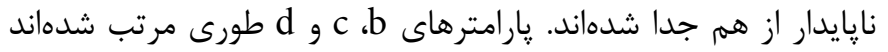

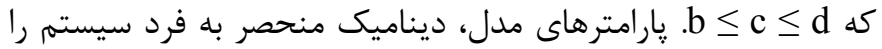
مشخص مى كنند، كه بازنمود فرد است (شكل (). بارامترها با توجه به

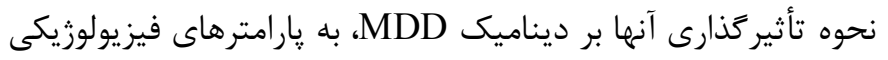

احتمالى نسبت داده شده است (جدول (1).
بدون علامت به سر مىبرد. سير زمانى متغير M در كامهاى زمانى گسسته طبق اين معادله ساده،

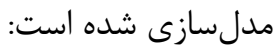

$M(t+\Delta t)=M(t)+\frac{d M}{d t} \Delta t$

در هر كام زمانى دt، خلق با مقدار

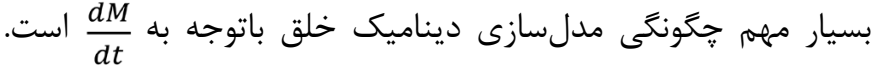
رفتار سيستم را به طور كامل ديناميك تعيين مى كند و همانطور كه در مقدمه به طور خلاصه كفته شد، بايد بتوان مشاهدات تجربى مهمم در MDD را توضيح دهد. هدف يافتن مدل سادهاى است كه بتواند بسيارى از مشاهدات بالينى مهم در ارتباط با MDD را به دست آورد.

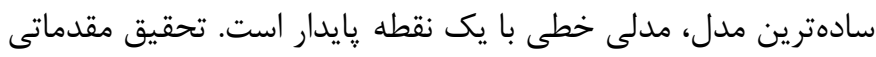

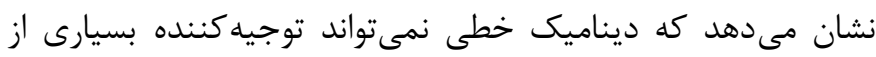

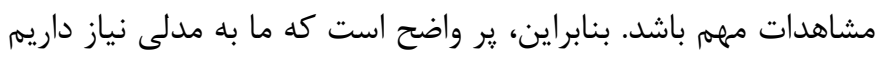

جدول ا. همبستههاى فيزيولوزيكى احتمالى بارامترهاى مدل (I")

\begin{tabular}{|c|c|c|}
\hline 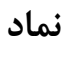 & 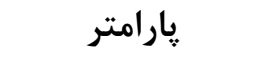 & همبسته هاى فيزيولوزيكى \\
\hline a & 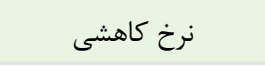 & حجم هييوكامب و نخ توليد نرونهاى بالغ \\
\hline $\mathrm{b}$ & نقطه ثابت پايدار منفى & سطح مونوآمينها و سروتونين \\
\hline $\mathrm{c}$ & نقطه ثابت نايايدار & c> • حالت بدبينى c> حالت خوشبينانه c> \\
\hline $\mathrm{d}$ & نقطه ثابت بايدار مثبت & فعاليت آميخدال \\
\hline $\mathrm{i}$ & 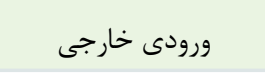 & تأثير محيط \\
\hline$\varepsilon$ & 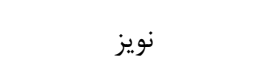 & ورودى هاى غير ييشبينى شده يا رفتارخارجى مؤثر در خلق \\
\hline
\end{tabular}

مدلسازى شده با فرد ديخر تفاوت داشته باشد ( آس). تصوير فاز، نمايشى هندسى، از ديناميك سيسته است. تصوير فاز، تمام

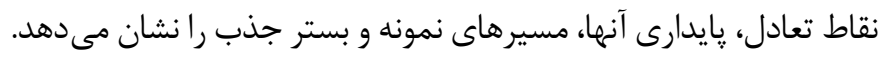

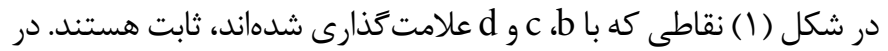
اين نقاط، مقدار تغيير صفر است. نقاط ثابت b و لِايدار هستند، به اين معنا كه سيستم اكر، اندكى آشفته شود، به اين حالات بر خواهد كشت.

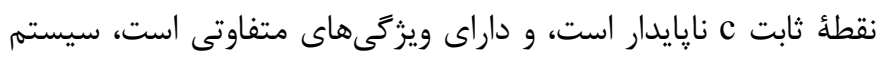
اكر اندكى آشفته شود، از نقطه c فاصله مى خيرد. در اين حالت، سيستم

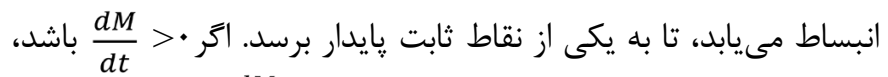

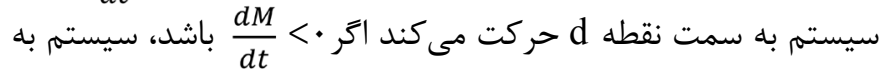

تمام افراد در زير جمعيت مدل، يارامترهاى يكسان و مشتركى دارند.

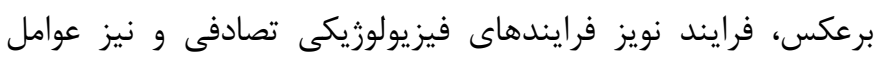

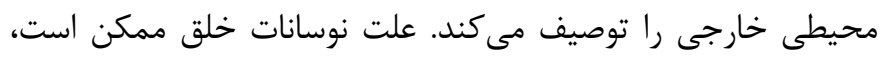

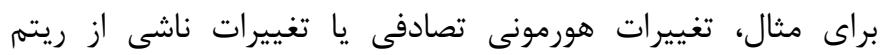
شبانهروزى باشد. تغييرات خارجى، يعنى موقعيتهاى استرسآور يا ليات

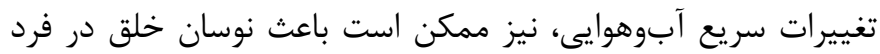
درطول روز شود. نام "الويزه به اين معنا نيست كه فرايند نويز بىربط

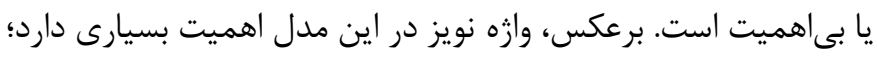

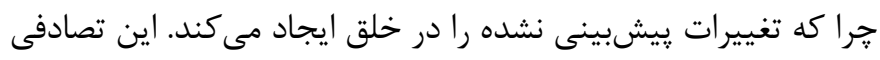

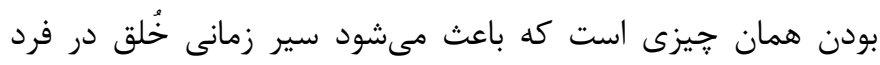




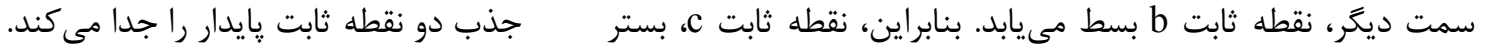
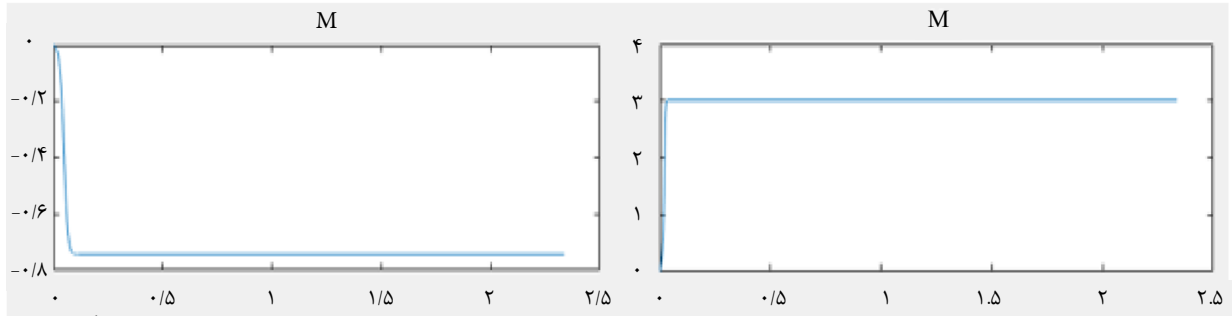

b

$\times 10^{4} \mathrm{C}$
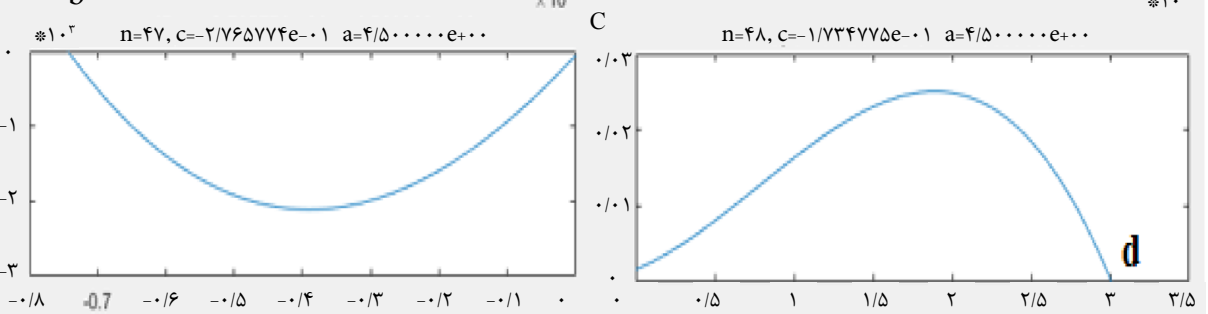

شكل ا. تصوير فاز يك بعدى، كه تغيير خلق را به صورت تابعى از متغير حالت M نشان مىدهد.

برداشته شده از يك متغير تصادفى تا جه حد به ميزان واقعى نزديك است از تست t استيودنت استفاده شد. لذا در مدل ديناميكى مقدار را كه متناسب با نرخ كاهشى هييو كامٍ است، با استفاده از مقادير استيودنت، براى شروع t t أ درصد و مقدار d كه متناسب با حجم آميگدال است عدد ه/T/ هاى گذارى شد. براى رسم فضاى فاز سيستم ديناميكى مرتبه يك و تغييرات نسبت به زمان مقادير اوليه زير، در كد نوشته شده در MATLAB، جاى كذارى شد. $a=r / \Delta, b=-\cdot / q, c=r($ rand $-\cdot / \Delta), d=\Delta / r \Delta, I=\cdot / \cdot r($ rand $-\cdot / \Delta)$, $\mathrm{dt}=\cdot /, \mathrm{M} 1=$.
قبل از ساختن مدل مرتبه دو لازم بود كه مدل مرتبه يك با دادههاى

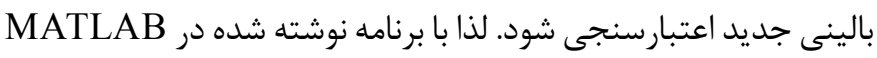
مدل مرتبه يك شبيه سازى شد، و فضاى فاز و گستره تغييرات كميتها مجدداً بررسى شد. دادههاى بيولوزيكى مربوط به ساختار هييوكامب و آميگدال با نرمافزار Python توسط Roddy در سال (^| • r) تحليل شده است و در سايت github قرار گرفته است (r (r). اين دادهها مربوط به حجم و ضخامت نواحى مختلف هييوكامٍ و آميگدال است. تفسير اين دادهها كه به صورت انيميشن نشان داده شده است، نشان مى دهد كه حجم هييو كامٍ در بيماران مبتلا به اختلال افسردگى اساسى كمتر از گروه كنترل است (Tr). براى بررسى اين نكته كه ميانگين نمونه بهاى

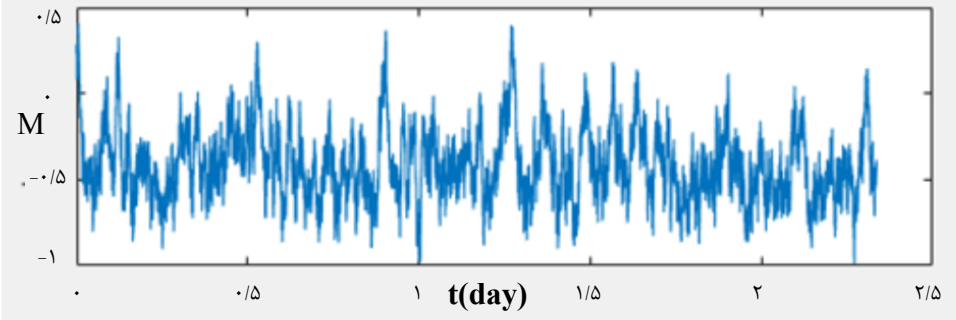

$\mathrm{dM} / \mathrm{dt}$

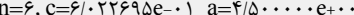

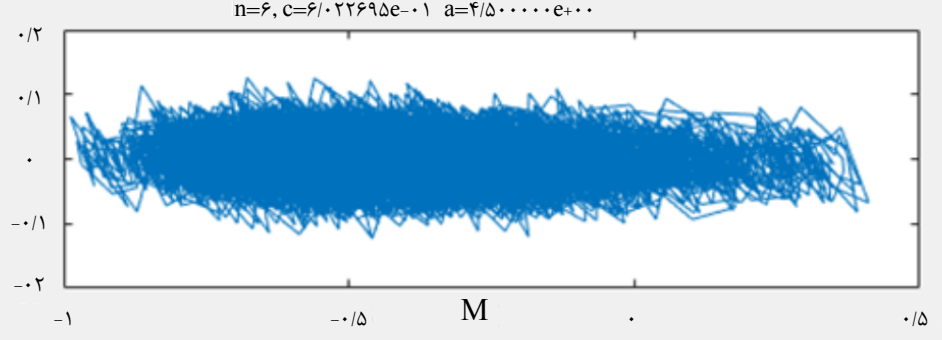

شكل r. تصوير فاز مدل سيستمهاى ديناميكى مرتبه يك با نويز زياد 
حالت دو بعدى تبديل مىشود، سيستمهاى دو بعدى غيرخطى مى توانند تعداد زيادى جاذب به طور همزمان داشته باشند. برخلاف سيستمهاى يك بعدى، در سيستمهاى دو بعدى نقاط تعادل نايايدار بسترهاى جذب را جدا نمى كنند. بسترهاى جذب توسط يك زوج مسير حركت، به نام جداكننده از هم جدا مى شوند. منظور ازخطوط صفر خطوطى هستند كه صفحه فاز را، به دو ناحيه، تقسيم مى كنند. و مجموعهاى از نقاط را، مشخص مى كنند، كه ميدان

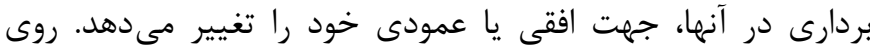

$$
\text { خطوط صفر •=ت }
$$

محل تقاطع خطوط صفر، نقاط تعادل سيستم است. اكر نقطه اوليه تزديك نقطه تعادل باشد، آنغاه بسته به نوع پايدارى، مسير حركت ممكن است به نقطه تعادل، همكرا و يا واگرا شود. در شكل (rا) تصوير فاز تنها يك جاذب دور حدى متناظر با دورههاى لهاى

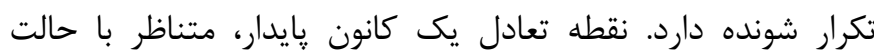

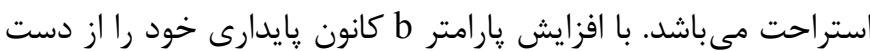
مى دهد و يك جاذب حلقه حدى با دامنه كوجك را را تشكيل مى دهد. دامنه دور حدى با افزايش b زياد مى شود. در اين حالت دو شاخكى از نوع آندرونوف_هويف خواهد بود. اين دو شاخكى مى تواند از نوع فوق

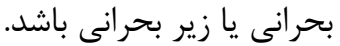

شكل (Y) فضاى فاز براى تغييرات M با نويز زياد را نشان مىدهد كه با افزايش نويز، ديناميك سيستم در سطح بالاترى رشد مى يابد. با افزايش نويز تغييرات M شديدتر شده و در خلق منفى و مثبت در بازههاى زمانى

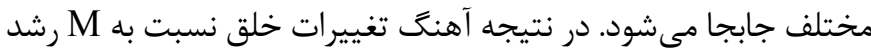
بسيار سريعترى كرفته و جهت آن همواره در حال تغيير است.

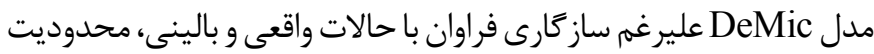

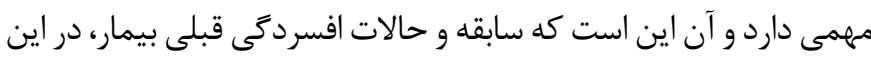

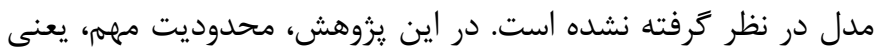
سابقه بيمار و دورههاى قبلى بيمار كه در وقوع حالت افسردگى بعدى، تطرى تأثير بسزايى دارد، مرتفع شده و براى اولين بار در نظر كرفته شد. براى

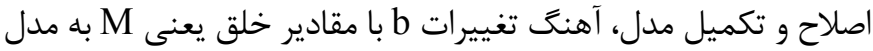
قبلى اضافه شده است. تغييرات b به صورت معادله زير مىباشد.

$\frac{\mathrm{db}}{\mathrm{dt}}=\mathrm{M}\left(\mathrm{b}-\mathrm{b}_{0}\right)$

در اين معادله b مكان اوليه نقطه ثابت بايدار منفى است. به عبارت ديكر در مدل ديناميكى سابقه و دوره قبلى بيمار است كه براى دوره بعدى در نظر كرفته مىشود. جون در هر دوره مكان اوليه نقطه نإيايدار تغيير

مى كند، لذا با اعمال تغييرات b سابقهى بيمار در مدل اعمال مى هـود. با اضافه كردن معادله (با)، سيستم ديناميكى از حالت يك بعدى قبلى به

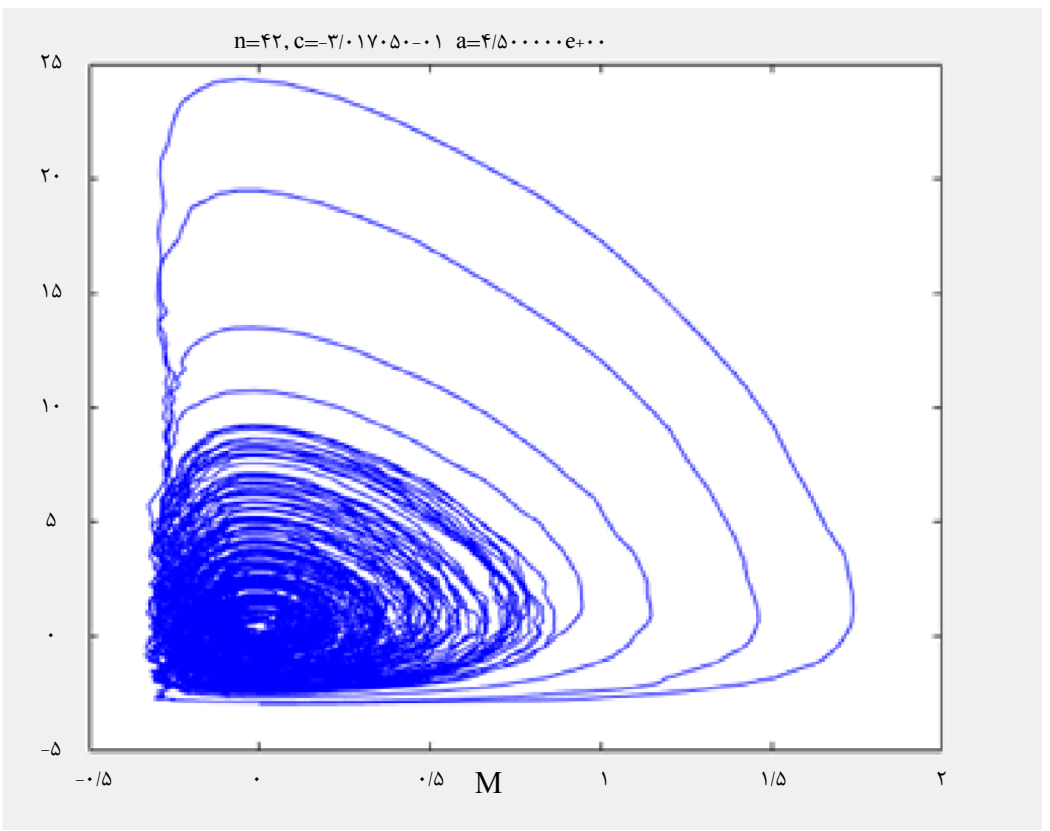

شكل r. فضاى فازى متناظر با متغيرهاى b M M در مدل سيستمهاى ديناميكى مرتبه دو با يك جاذب 
جند دوره افسردگى (NuMber of Depressive Episodes (NDE) برابر است.

$\mathrm{OR}=\frac{\sum(N D E \geq 1)}{n}$

سرعت اولين بازگشت (Rate of First Recurrence (RR1) كسرى

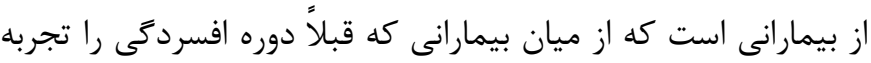
كردهاند، براى بار دوم به افسردگى مبتلا مىشوند.

$\operatorname{RR}(1)=\frac{\sum(N D E \geq 2)}{\sum(N D E \geq 1)}$
دوشاخكى آندرونوف_هويف فوق بحرانى متناظر با به وجود آمدن يك جاذب حلقه حدى با دامنه كم است. دوشاخكى آندرونوف_هويف زير بحرانى متناظر با از بين رفتن يك دور حدى نايايدار مىباشد. مطابق شكل (I) تغييرات b در بازهى دادههاى بالينى محدود شده است، به عبارت ديگر مدل در هر اجرا مقدار b حالت قبلى را به عنوان مقدار اوليه سطح سروتونين در نظر مى گيرد.

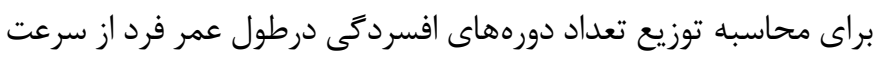
وقوع و بازگشت علائم استفاده شد؛ سرعت (Occurrence Rate (OR) كسرى از جمعيت است كه دستكم يك بار در طول عمر به دوره افسردگى دجار شدهاند. بنابراين سرعت وقوع با احتمال داشتن يك يا

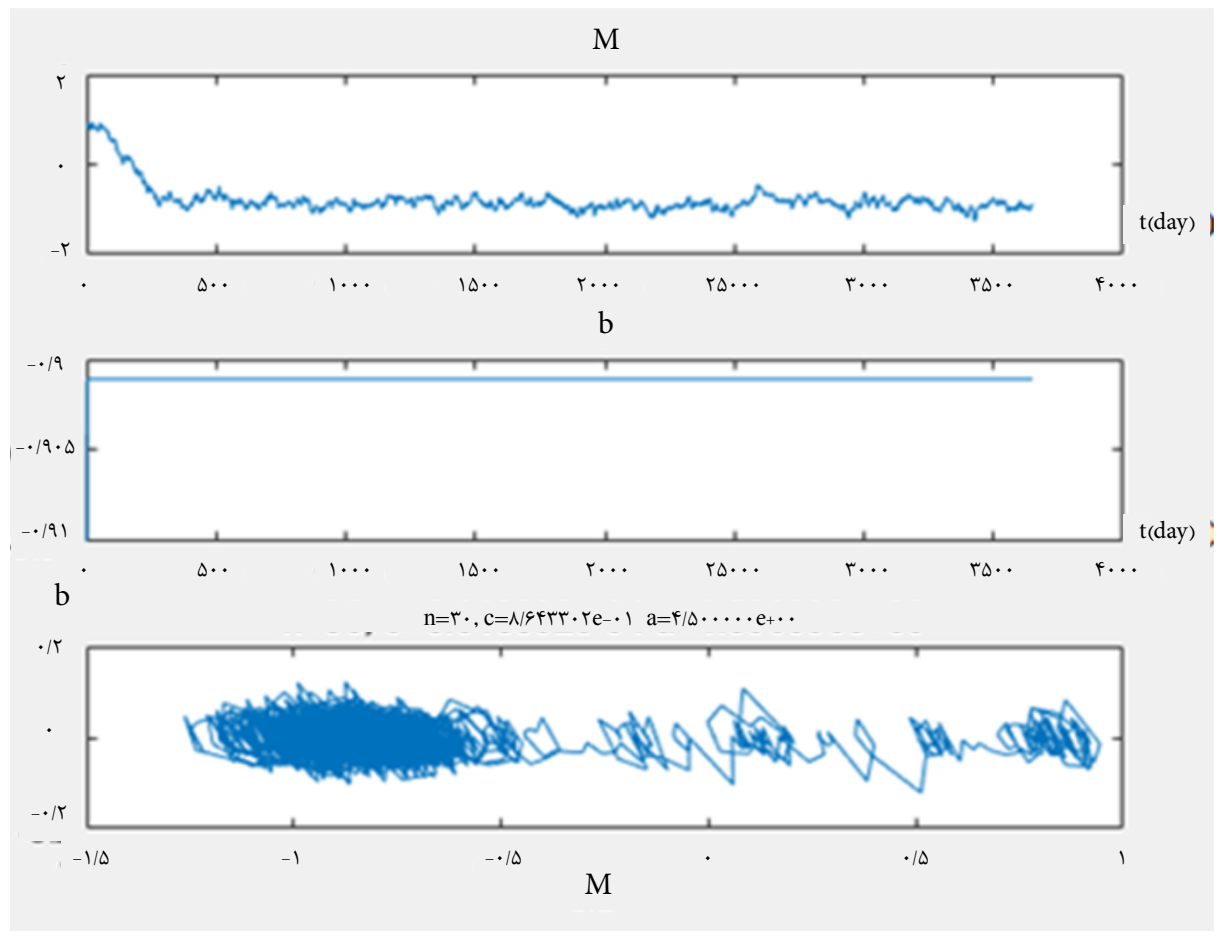

شكل F. فضاى فازى متناظر با متغيرهاى M و b در مدل سيستمهاى ديناميكى مرتبه دو با گستره محدودb

بايد دست كم جههارده روز علائم را داشته باشد تا بتوان آن دوره را دوره افسردگى ناميد.

دادههاى مدل با استفاده از توزيع يكنواخت و تشخيص رياضى صورت كرفت. دادههاى تجربى از نمونههاى بالينى كه توسط Muller و

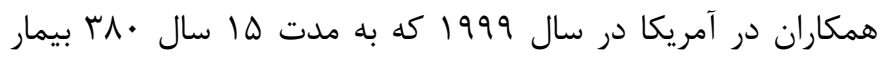

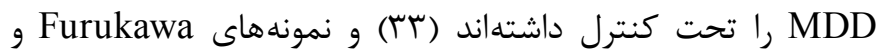

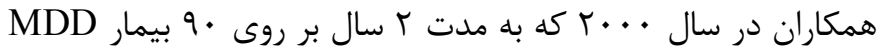
صورت گرفته بود (Fr) و همجنين از نمونههاى Spijker و همكاران

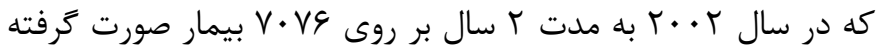
بود، به دست آمده است (ه山).
براى بررسى سرعت OR و RR، به سيستم در حالت مثبت مقدار اوليه

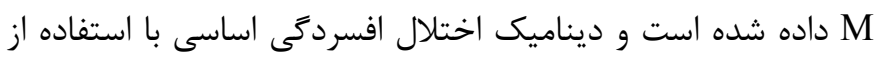

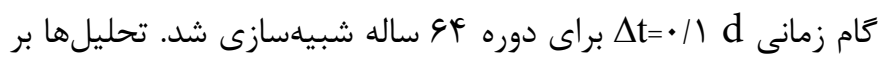
اساس شبيهسازى r + · نفر انجام مىشود. براى اين كه زمانِ تقليل علائم و زمان واكنش در مدل مطالعه شود، به سيستم در حالت منفى

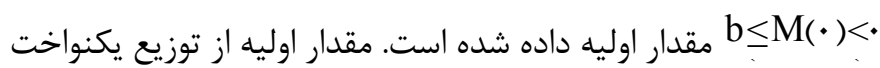
در گستره دادههاى بالينى، گرفته مى شود. در حالت دوره افسردگى بازگشتى مقدار اوليه داده و زمان افزايش متغير M بيش از • ه درصد را زمان واكنش و زمان وقوع نخستين تقليل با بهبود علائم را زمان تقليل در نظر مى گيريم. به زمانِ تقليل جهارده روز افزوده مىشود؛ زيرا فرد 
عمر بيماران و همينطور در شبيهسازىهاى نظرى از آن بهره كرفت. به كمك برنامهنويسى به زبان MATLAB معادلات ديناميكى ييشبينى شده و ماشين حالات افسردگى به صورت نرمافزار تهيه شده

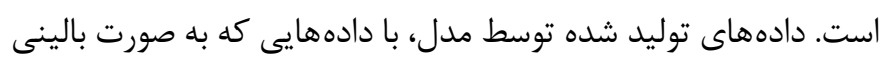

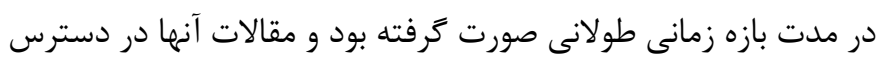
بود، مقايسه شد.

\section{يافته ها}

نتايج مدل حاكى از آن است كه، در سيستم ديناميكى مرتبه ب مدل دجار دوره حدى مى شود و سابقه دورههاى قبلى در سيستم اعمال مى شى دود.

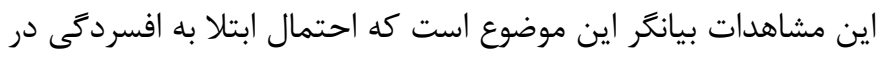

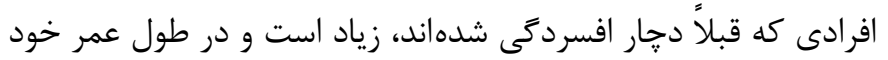

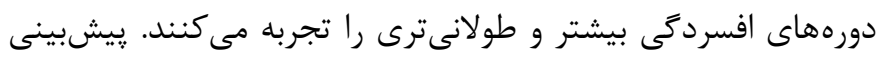

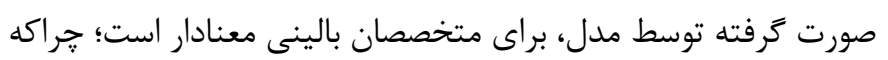

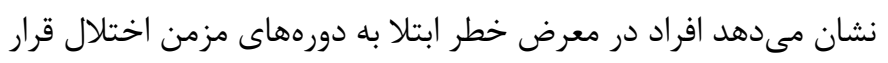

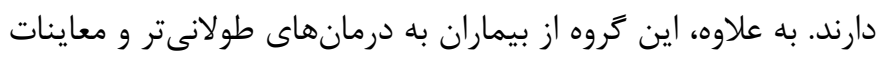

$$
\text { منظهمترى بعد از بهبودى نيازمند هستند. }
$$

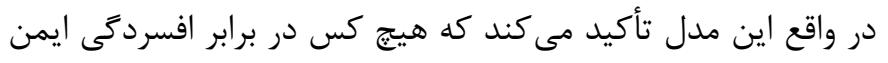

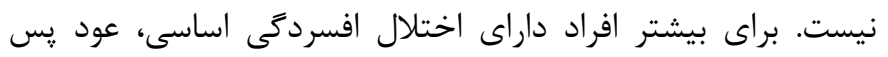

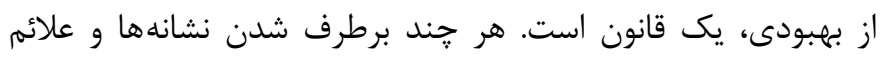

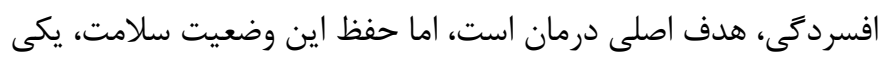

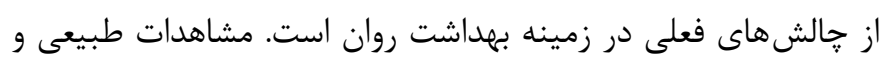

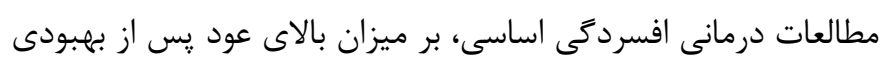

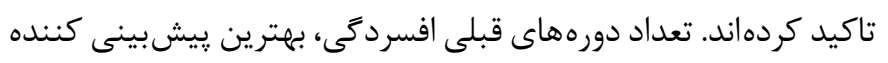

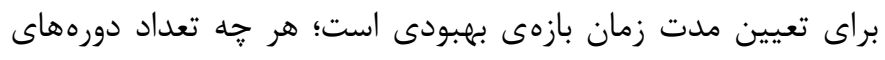

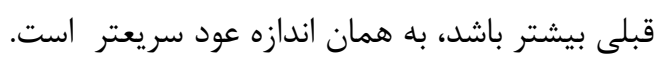

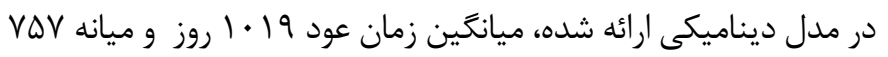

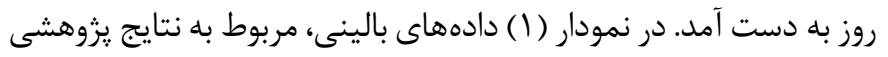

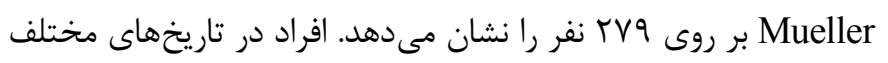

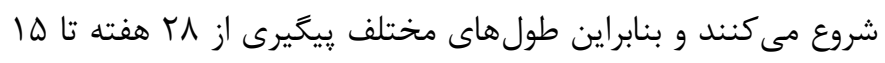

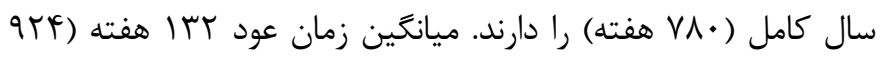

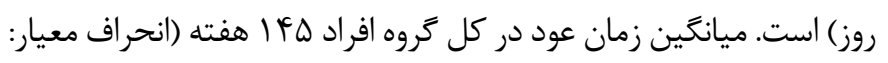

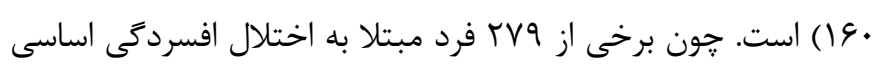

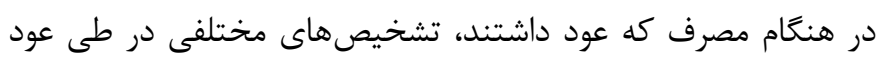

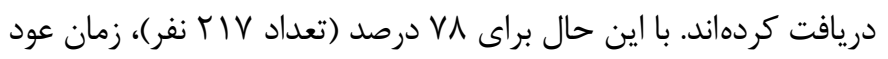

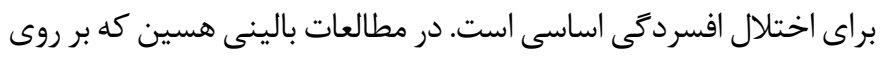

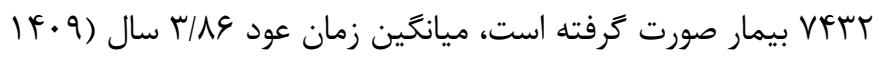

اين مدل رياضياتى، مراحل انتقال متغيير M، از حالت بدون علامت،

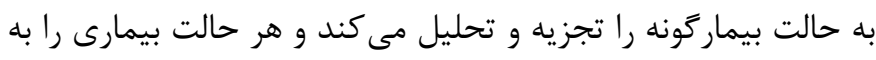

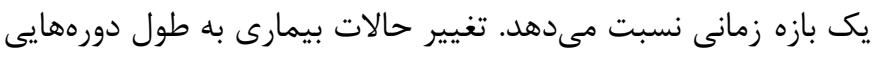

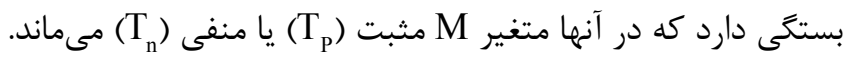

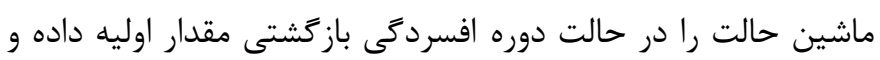

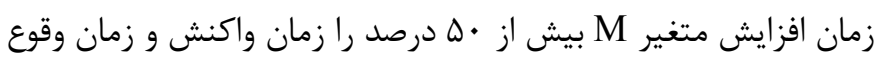

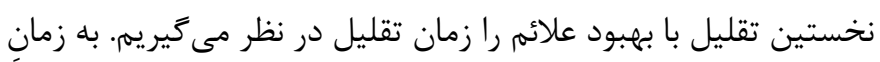

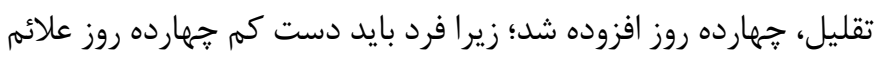

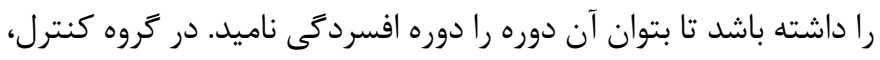

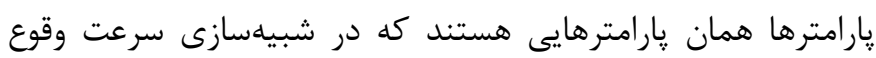

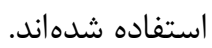
دوره افسردىى ممكن است با تقليل علائم متوقف شود، كه به صورت دورهاى بدون علامت به مدت دست كم دو هفته تعريف مىشود. تقليل

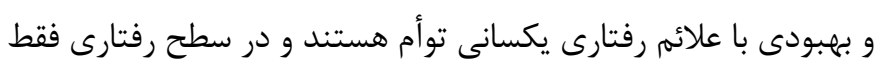

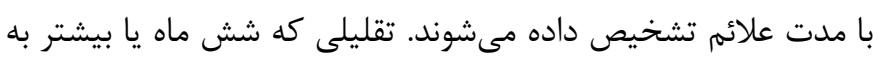

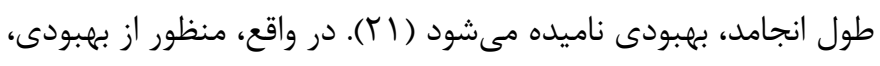

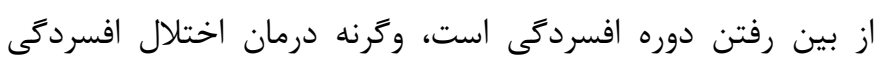

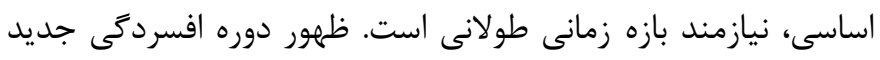

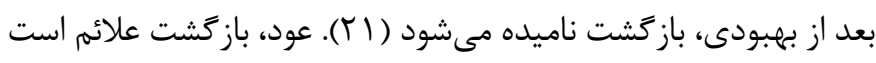

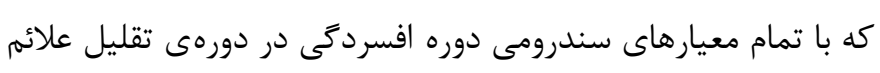

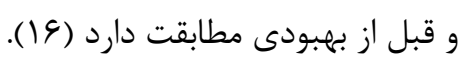

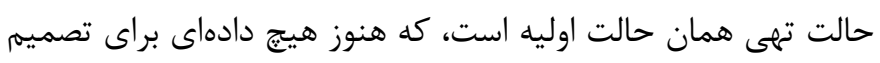

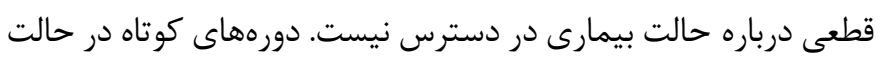

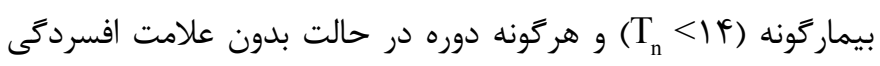
تغييرى در حالت تهى ايجاد نخواهد كرد. اكر أl (T)

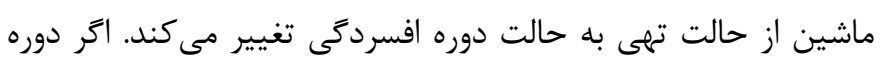

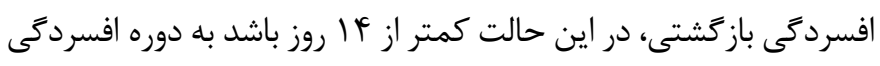

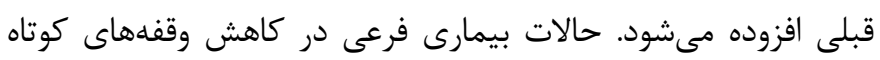

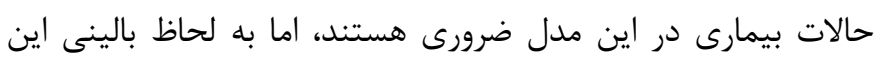

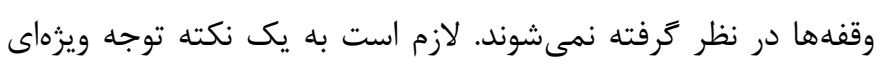

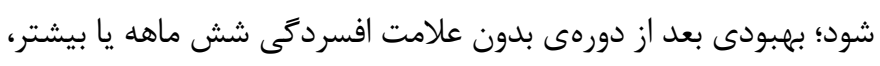

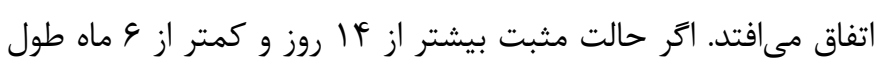
بكشد، در اين صورت ماشين اين دوره را، دوره تقليل علائم مى منامد.

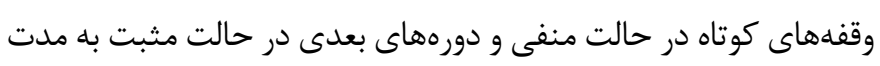

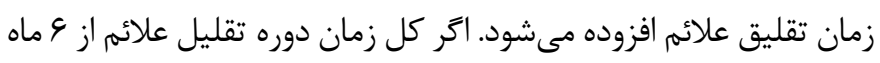

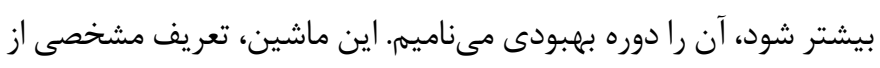

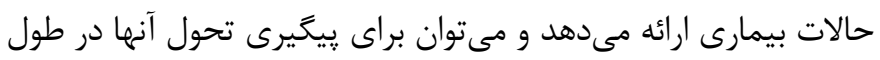


با توجه به اينكه براى يارامتر c كه نقطه تعادل نايايدار مدل است، در برنامه MATLAB 91 عدد و براى يارامتر I كه عوامل محيطى و شناختى مدل است، در برنامه 1 عدد انتخاب مىشود، خروجى

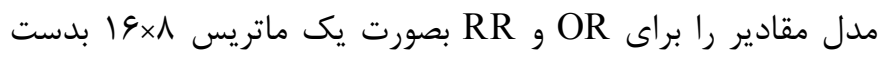

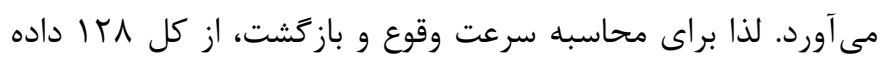
بدست آمده، مقادير كمتر از ميانگين، در نظر گرفته شد. در نمودار (Y) دادههاى مدل مرتبه دو، نسبت به مدل DeMic، تطابق بهترى با سرعتهاى تجربى وقوع و بازگشت دادهاى بالينى دارد. اين نتيجه بيانگر آن است كه مدل سيستم مرتبه دو توانسته است محدوديت مدل مرتبه يك را رفع نمايد.
روز) به دست آمده است (צץ). در مدل ديناميكى ارائه شده، ميانگين زمان عود 19 • • روز بدست آمده است. آر هدف مدل، نشان دادن جنبههاى ديناميك MDD باشد، بايد بتواند دادهاى بالينى مربوط به سرعت وقوع و باز گشت MMD را توضيح دهد.

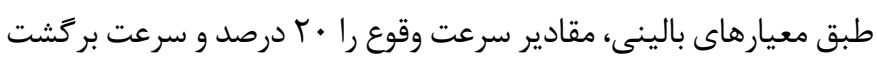

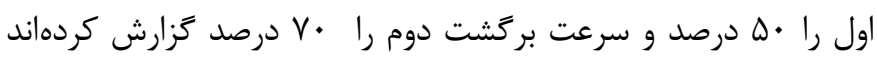

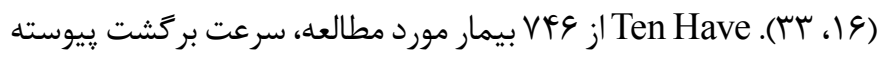

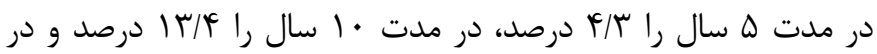

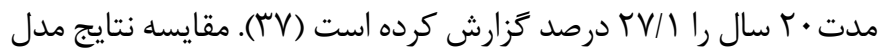
با دادهاى بالينى و مدل مرتبه يك در نمودار (r) گزارش شده است.

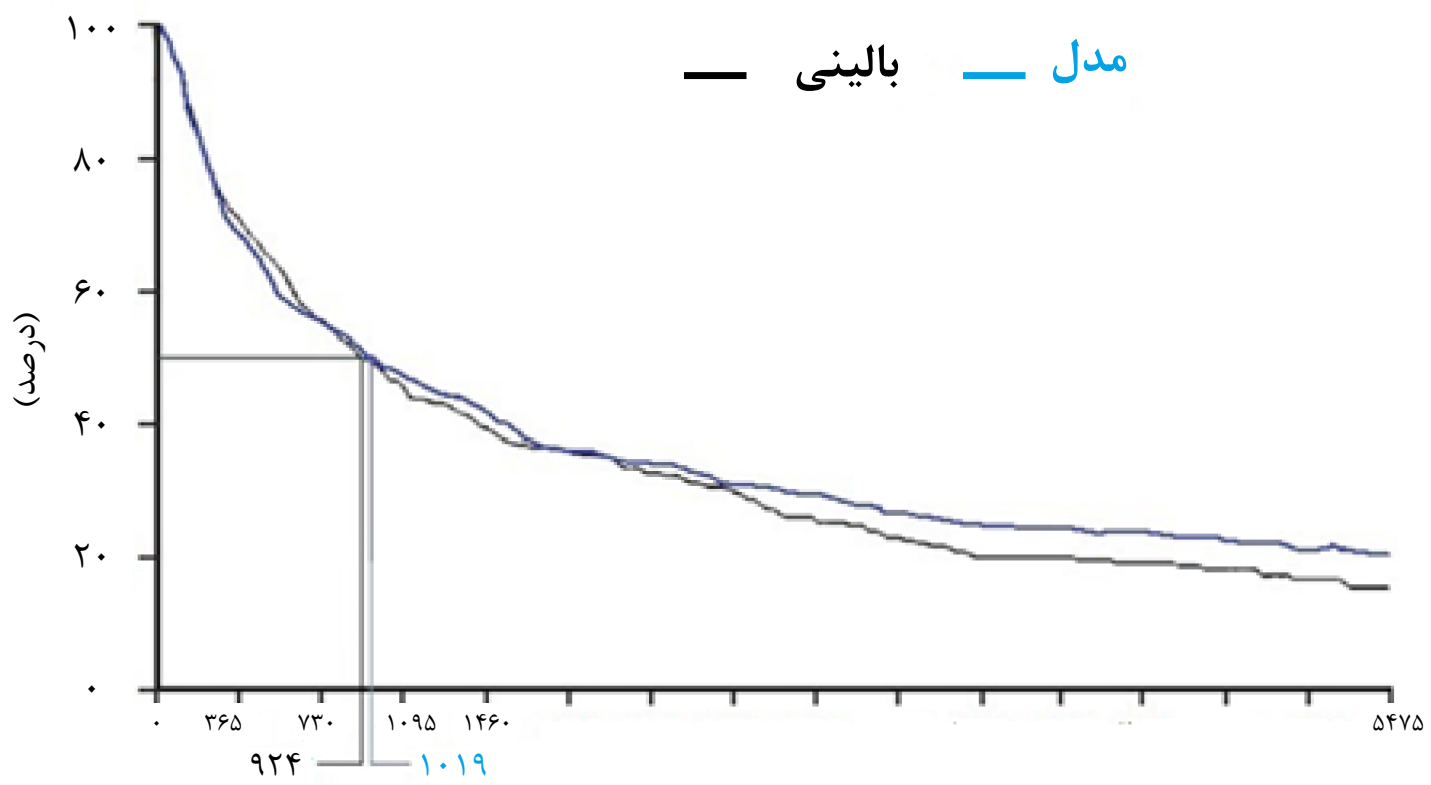

نمودار 1. زمان عود افرادى كه از دوره اختلال افسردكى بهبود يافتهاند.

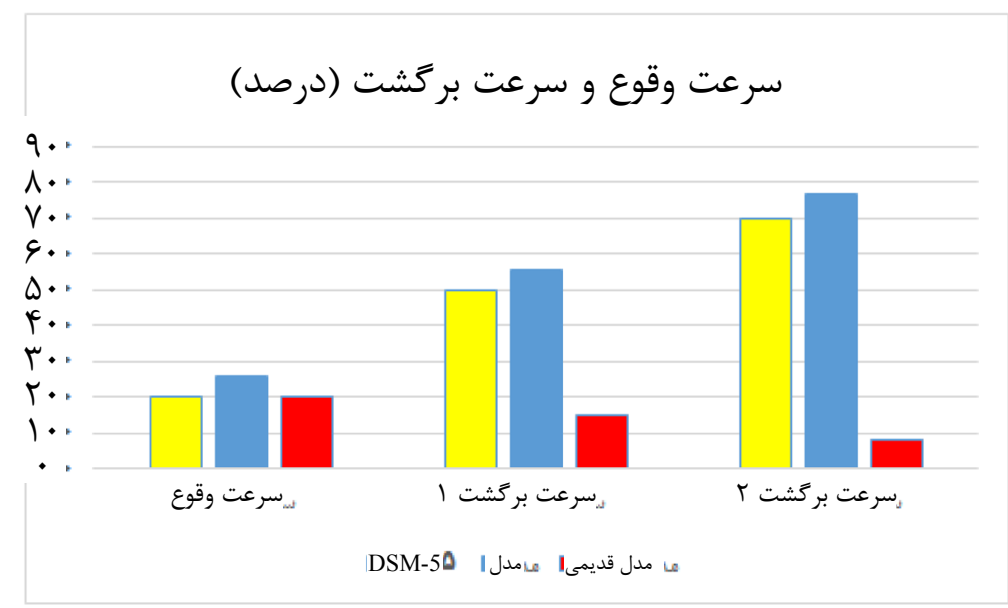

نمودار r. مقايسه سرعت وقوع و بازگشت مدل مرتبه دو با دادههاى بالينى و مدل مرتبه يك 


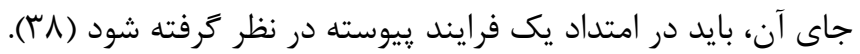

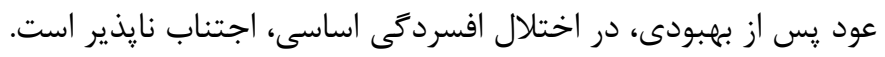

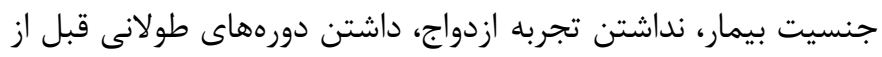
شروع درمان و داشتن تعداد دورههاى قبلى بيشتر، ويزگى هايى است

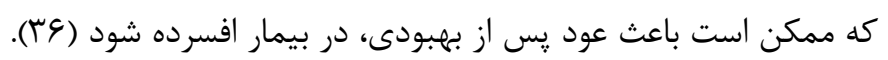

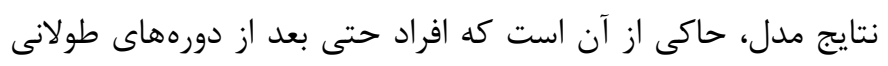

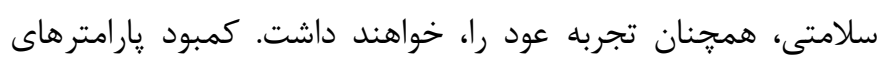

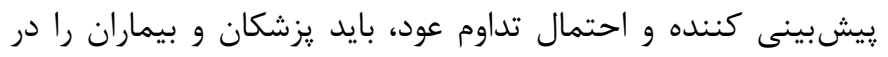
مورد عود افسردىى و علائم مضر افسردىى، هشيار سازد. مطالعات انجام ندام

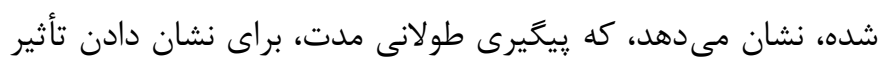

$$
\text { جنسيت بر عود، ضرورى است (Y (Y). }
$$

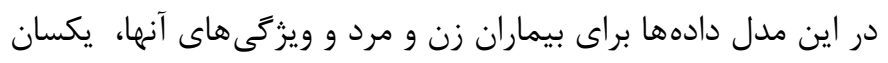

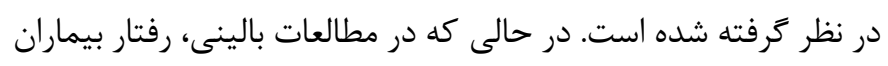

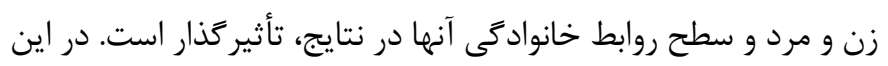

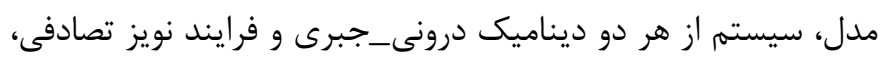

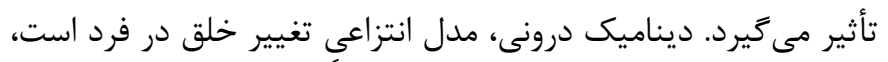

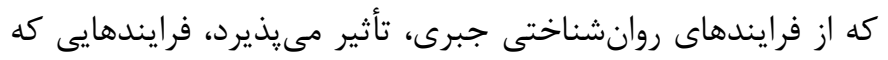
به صورت ديناميكى در اينجا مدلسازى نشده است.

با توسعه مدل ديناميكى از مرتبه يك به مرتبه دو سرعت وقوع و سرعت

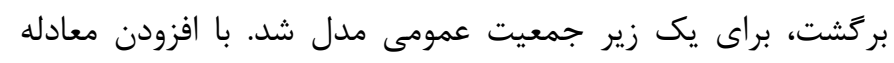

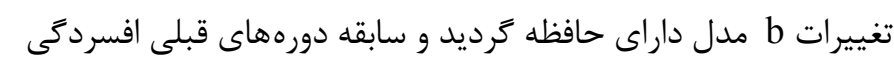

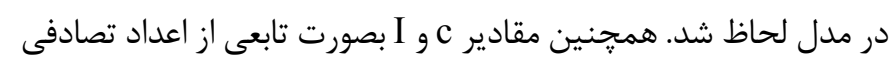

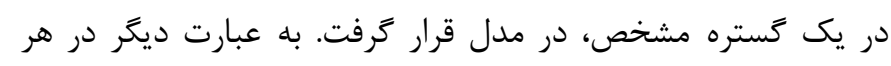

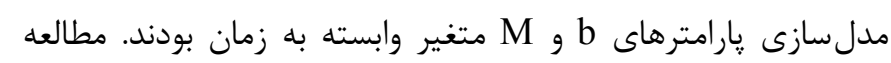

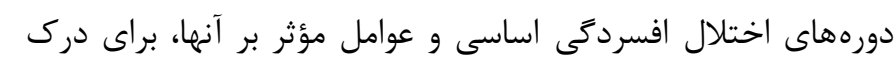

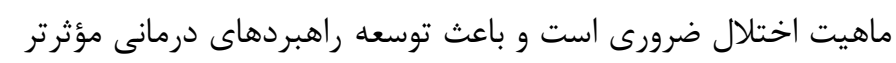

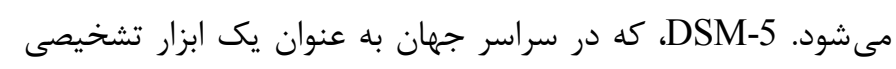

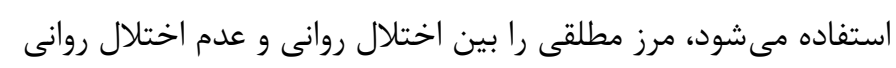

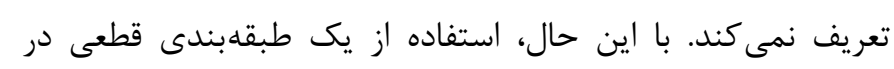

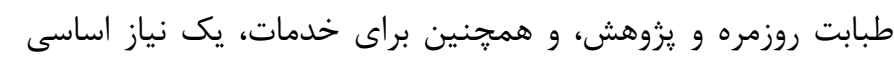

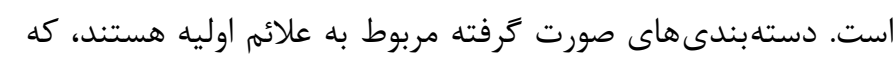

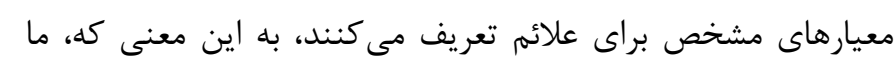

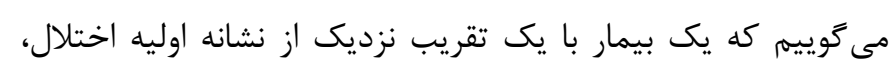

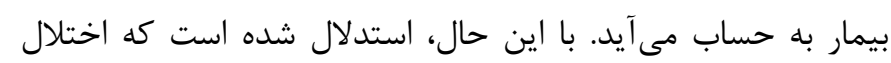

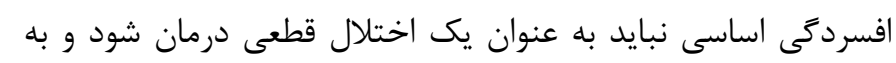

\section{جدول r. مقايسه معيارهاى كمى بيشرفت بيمارى بين مدل و مشاهدات بالينى}

\begin{tabular}{|c|c|c|}
\hline نتايج مدل & مشاهدات & متغييرها \\
\hline ( 19 & 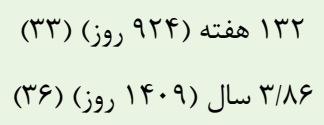 & ميانكَين زمان عود \\
\hline T To/V درصد & 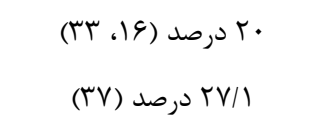 & سرعت وقوع (OR) \\
\hline ه ه هرصد & 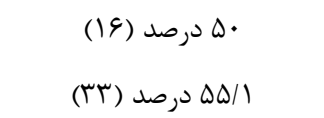 & سرعت اولين بركشت (RR) \\
\hline
\end{tabular}

\section{تشكر و قدردانى}

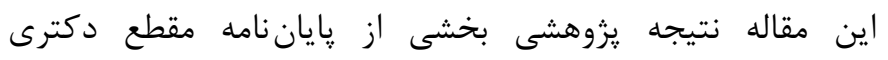

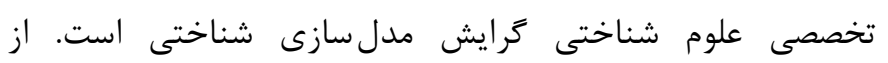

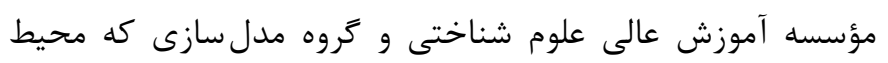

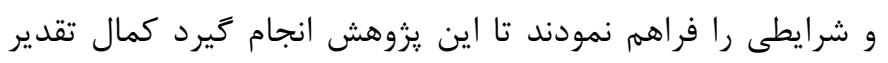
و تشكر را داريم.

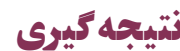

با توجه به دادههاى موجود، مدل متناسبى بيان شده است. قطعاً به دليل

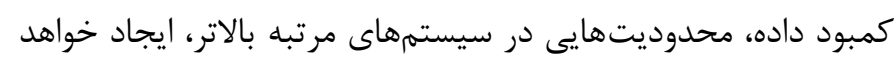

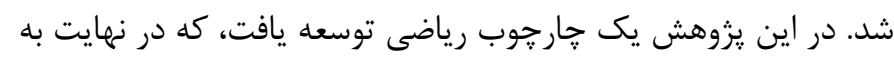

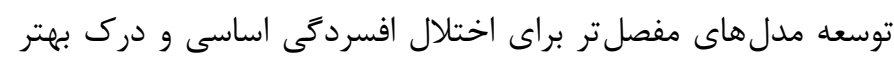

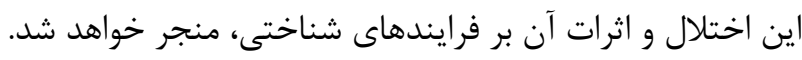




\section{References}

1. Otte C, Gold SM, Penninx BW, Pariante CM, Etkin A, Fava M, et al. Major depressive disorder. Nature Reviews Disease Primers. 2016;2(1):1-20.

2. Kessler RC, Angermeyer M, Anthony JC, De Graaf RO, Demyttenaere K, Gasquet I, et al. Lifetime prevalence and ageof-onset distributions of mental disorders in the World Health Organization's World Mental Health Survey Initiative. World Psychiatry. 2007;6(3):168-176.

3. World Health Organization. The global burden of disease:Geneva;2008.

4. Curran C, Knapp M, McDaid D, Tómasson K, Mheen Group. Mental health and employment: An overview of patterns and policies across Western Europe. Journal of Mental Health. 2007;16(2):195-209.

5. Hasler G. Pathophysiology of depression: Do we have any solid evidence of interest to clinicians?. World Psychiatry. 2010;9(3):155-161.

6. World Health Organization. Depression and other common mental disorders:Global health estimates;2017.

7. Gabilondo A, Rojas-Farreras S, Vilagut G, Haro JM, Fernán$\operatorname{dez}$ A, Pinto-Meza A, et al. Epidemiology of major depressive episode in a southern European country: Results from the ESEMeD-Spain project. Journal of Affective Disorders. 2010;120(1-3):76-85.

8. Hayes AM, Yasinski C, Barnes JB, Bockting CL. Network destabilization and transition in depression: New methods for studying the dynamics of therapeutic change. Clinical Psychology Review. 2015;41:27-39.

9. Kessler RC, Bromet EJ. The epidemiology of depression across cultures. Annual Review of Public Health. 2013;34:119-138.

10. Sharifi V, Amin-Esmaeili M, Hajebi A, Motevalian A, Radgoodarzi R, Hefazi M, et al. Twelve-month prevalence and correlates of psychiatric disorders in Iran: The Iranian mental health survey, 2011. Archives of Iranian Medicine. 2015;18(2):76-84.

11. Peters KM, Killinger KA, Jaeger C, Chen C. Pilot study ex- ploring chronic pudendal neuromodulation as a treatment option for pain associated with pudendal neuralgia. LUTS: Lower Urinary Tract Symptoms. 2015;7(3):138-142.

12. De Macedo-Soares MB, Moreno RA, Rigonatti SP, Lafer B. Efficacy of electroconvulsive therapy in treatment-resistant bipolar disorder: A case series. The Journal of ECT. 2005;21(1):31-34.

13. Conti CL, Da Silva-Conforti AM. A brief review on epigenetic aspects involved in depression. Biology and Medicine. 2016;8(5):1000315.

14. Flint J, Kendler KS. The genetics of major depression. Neuron. 2014;81(3):484-503.

15. Hornung O, Heim C. Gene-environment interactions and intermediate phenotypes: Early trauma and depression. Frontiers in Endocrinology. 2014;5:14.

16. Association AP. Diagnostic and statistical manual of mental disorders (DSM-5®). Arlington VA:American Psychiatric Pub;2013.

17. Kennedy SH. Core symptoms of major depressive disorder: Relevance to diagnosis and treatment. Dialogues in Clinical Neuroscience. 2008;10(3):271-277.

18. Hollon SD, DeRubeis RJ, Evans MD, Wiemer MJ, Garvey MJ, Grove WM, et al. Cognitive therapy and pharmacotherapy for depression: Singly and in combination. Archives of General Psychiatry. 1992;49(10):774-781.

19. Kheirbek MA, Klemenhagen KC, Sahay A, Hen R. Neurogenesis and generalization: A new approach to stratify and treat anxiety disorders. Nature Neuroscience. 2012;15(12):1613-1620.

20. Moore MT, Fresco DM. Depressive realism: A meta-analytic review. Clinical Psychology Review. 2012;32(6):496-509. 21. Frank E, Prien RF, Jarrett RB, Keller MB, Kupfer DJ, Lavori $\mathrm{PW}$, et al. Conceptualization and rationale for consensus definitions of terms in major depressive disorder: Remission, recovery, relapse, and recurrence. Archives of General Psychiatry. 1991;48(9):851-855.

22. Dickerson BC, Eichenbaum H. The episodic memory sys- 
tem: Neurocircuitry and disorders. Neuropsychopharmacology. 2010;35(1):86-104.

23. Thompson C. Onset of action of antidepressants: results of different analyses. Human Psychopharmacology: Clinical and Experimental. 2002;17(S1):27-32.

24. Kessler RC, Berglund P, Demler O, Jin R, Koretz D, Merikangas KR,et al. The epidemiology of major depressive disorder: Results from the National Comorbidity Survey Replication (NCS-R). Jama. 2003;289(23):3095-3105.

25. Homer JB, Hirsch GB. System dynamics modeling for public health: Background and opportunities. American Journal of Public Health. 2006;96(3):452-458.

26. Schaub H, Schiepek G. Simulation of psychological processes: Basic issues and an illustration within the etiology of a depressive disorder. In Tschacher W, Schiepek G, Brunner EJ, editors. Self-organization and clinical psychology. Berlin:Springer;1992. pp. 121-149.

27. LiKamwa R, Liu Y, Lane ND, Zhong L. MoodScope: Building a mood sensor from smartphone usage patterns. In Proceeding of the 11th Annual International Conference on Mobile Systems, Applications, and Services, MobiSys 2013. June 25; New York, USA;2013. pp. 389-402.

28. Tomitaka S, Furukawa TA. Mathematical model for the distribution of major depressive episode durations. BMC Research Notes. 2014;7(1):636.

29. Bonsall MB, Geddes JR, Goodwin GM, Holmes EA. Bipolar disorder dynamics: Affective instabilities, relaxation oscillations and noise. Journal of the Royal Society Interface. 2015;12(112):20150670.

30. Schiepek G, Aas B, Viol K. The mathematics of psychotherapy-a nonlinear model of change dynamics. Nonlinear Dynamics, Psychology, and Life Sciences. 2016;20(3):369-399.
31. Demic S, Cheng S. Modeling the dynamics of disease states in depression. PloS One. 2014;9(10):e110358.

32. Roddy DW, Farrell C, Doolin K, Roman E, Tozzi L, Frodl $\mathrm{T}$, et al. The hippocampus in depression: More than the sum of its parts? Advanced hippocampal substructure segmentation in depression. Biological Psychiatry. 2019;85(6):487-497.

33. Mueller TI, Leon AC, Keller MB, Solomon DA, Endicott J, Coryell W, Warshaw M, Maser JD. Recurrence after recovery from major depressive disorder during 15 years of observational follow-up. American Journal of Psychiatry. 1999;156(7):1000-1006.

34. Furukawa TA, Kitamura T, Takahashi K. Time to recovery of an inception cohort with hitherto untreated unipolar major depressive episodes. The British Journal of Psychiatry. 2000;177(4):331-355.

35. Spijker JA, De Graaf R, Bijl RV, Beekman AT, Ormel J, Nolen WA. Duration of major depressive episodes in the general population: Results from The Netherlands Mental Health Survey and Incidence Study (NEMESIS). The British Journal of Psychiatry. 2002;181(3):208-213.

36. Hasin DS, Sarvet AL, Meyers JL, Saha TD, Ruan WJ, Stohl M, et al. Epidemiology of adult DSM-5 major depressive disorder and its specifiers in the United States. JAMA Psychiatry. 2018;75(4):336-346.

37. Ten Have M, De Graaf R, Van Dorsselaer S, Tuithof M, Kleinjan M, Penninx BW. Recurrence and chronicity of major depressive disorder and their risk indicators in a population cohort. Acta Psychiatrica Scandinavica. 2018;137(6):503-515. 38. Widiger TA, Samuel DB. Diagnostic categories or dimensions? A question for the Diagnostic and statistical manual of mental disorders--fifth edition. Journal of Abnormal Psychology. 2005;114(4):494-504. 